\title{
REVIEW ARTICL
}

\section{Zika Virus: A Global Threat}

\author{
*J Fardows ${ }^{1}$, N Farhana ${ }^{2}$, A B Siddique ${ }^{3}$ \\ ${ }^{1}$ Dr. Jannatul Fardows, Assistant professor, Department of Microbiology \\ Kumudini Women's Medical College, Mirzapur, Tangail \\ ${ }^{2}$ Dr. Nasreen Farhana, Lecturer, Department of Microbiology, Dhaka Medical College, Dhaka \\ ${ }^{3}$ Dr. Abu Bakar Siddique, Assistant Register, Department of Medicine, Dhaka Medical College, Dhaka \\ * Corresponding author
}

Date of submission: 04 November $2015 \quad$ Date of acceptance: 12March 2016

\begin{abstract}
Zika virus is a enveloped, non-segmented, ichoshedral single-stranded, negative-sense RNA virus. It belongs to the Flaviviridae and was first isolated in 1947 from a monkey in the Zika forest, Uganda, then in mosquitoes (Aedes africanus) in the same forest in 1948 and in a human in Nigeria in 1952. Before 2007, viral circulation and a few outbreaks were documented in tropical Africa and in some areas in Southeast Asia. In 2015, Zika viral disease outbreaks were reported in Brazil of South America for the first time and it is now considered as an emerging infectious disease. This ongoing outbreak of Zika virus that began in Brazil has spread too much of South and Central America (except Canada and Chile) and the Caribbean. According to the CDC, Brazilian health authorities reported more than 404 cases of microcephaly between October 2015 and January 2016. Seventeen of those cases have a confirmed link to the Zika virus. Its natural reservoir is yet to be unknown. Transmission mainly by mosquito Aedes aegypti but it can be transmitted from human to human by blood transfusion, saliva, urine and sexual contact. Most dangerous transmission is mother to fetus through placenta. Its actual pathogenesis is not clear but the pathogenesis of the virus is hypothesized to start with an infection of dendritic cells near the site of inoculation, followed by a spread to lymph nodes and the bloodstream Other than congenital malformation (microcephaly) disease symptoms are usually mild and short-lasting self-limiting febrile illness of 4-7 days duration without severe complications. No commercial diagnostic method against Zika virus are available. The virus constitutes an important public health threat in America and also worldwide as no effective treatment or vaccine is available till now. The World Health Organization (WHO) has declared the microcephaly condition, linked to the mosquito-borne virus, a global public health emergency.
\end{abstract}

Key Words: Zika virus, microcephaly, Aedes aegypti, global threat

\section{Introduction}

Zika virus is the causative agent of the ongoing epidemic in America ${ }^{1}$. Zika virus disease is an emerging disease caused by a virus from the Flaviviridae family and Aedes mosquitoes are considered as main vectors. There are two Zika viral lineages: the African lineage and the Asian lineage which has recently emerged in the Pacific and the Americas ${ }^{2}$. Before 2007, viral circulation and a few outbreaks were documented in tropical Africa and in some areas in Southeast Asia. Since 2007, several islands of the Pacific region have experienced outbreaks. In 2015, Zika viral disease outbreaks were reported in Brazil of South America for the first time and it is now considered as an emerging infectious disease ${ }^{3}$. A significant increase of patients with Guillain-Barré syndrome (GBS) was reported during the 2014 outbreak in French Polynesia. A similar increase along with an unusual increase of congenital microcephaly was observed in some regions in north eastern Brazil in 2015. Causal relationships are currently under investigation 4 . Though Zika infections are generally confined to America, there is always a risk of spreading to the rest of the world and at present there is no 
AKMMC J $2016: 7(2)$

prophylaxis, treatment or vaccine to protect against infection $^{3}$. Therefore, preventive personal measures are recommended to avoid mosquito bites during the daytime ${ }^{5}$.

\section{History and Geographical Distribution}

Zika virus was first isolated in 1947 from a monkey in the Zika forest, Uganda, then in mosquitoes (Aedes africanus) in the same forest in 1948, and in a human in Nigeria in $1952^{5}$. Serological surveys in Africa and Asia indicate a most likely silent Zika viral circulation with detection of specific antibodies in various animal species (large mammals such as orangutans, zebra, elephants, water buffaloes) and rodents $^{2}$. The knowledge of geographical distribution of Zika virus is based on results of serosurveys, viral isolation in mosquitoes and humans, reports of travel-associated cases and very few published outbreaks. Before 2007, the areas with reported Zika viral circulation included tropical Africa and Southeast Asia ${ }^{4}$.

The first outbreak outside of Africa and Asia occurred on the island of Yap in the Federated States of Micronesia in 2007, characterized by rash, conjunctivitis, and arthralgia, which was initially thought to be dengue, Chikungunya, or Ross River disease 6. However, serum samples from patients in the acute phase of illness contained RNA of Zika virus. There were 49 confirmed cases, 59 unconfirmed cases, no hospitalizations, and no deaths ${ }^{7}$. Between 2013 and 2015, several significant outbreaks were notified on islands and archipelagos from the Pacific region including a large outbreak in French Polynesia. In 2015, Zika virus emerged in South America with widespread outbreaks reported in Brazil and Columbia ${ }^{3}$.

\section{Recent situation}

Since April 2015, a large, ongoing outbreak of Zika virus that began in Brazil has spread too much of South and Central America (except Canada and Chile) and the Caribbean. In January 2016, the CDC issued a level 2 travel alert for people traveling to regions and certain countries where Zika virus transmission is ongoing ${ }^{8}$. The agency also suggested that women thinking about becoming pregnant should consult with their physicians before traveling ${ }^{9}$. Governments or health agencies of the
*J Fardows, N Farhana, A B Siddique

United Kingdom, Ireland, New Zealand, Canada and the European Union soon issued similar travel warnings ${ }^{10}$. In Colombia, Minister of Health and Social Protection Alejandro Gaviria Uribe recommended to avoid pregnancy for eight months, while the countries of Ecuador, El Salvador, and Jamaica have issued similar warnings ${ }^{11,12}$. Plans were announced by the authorities in Rio de Janeiro, Brazil, to try to prevent the spread of the Zika virus during the 2016 Summer Olympic Games in that city $^{12}$. According to the CDC, Brazilian health authorities reported more than 404 confirmed cases of microcephaly between October 2015 and January 2016. Seventeen of those cases have a confirmed link to the Zika virus by real time PCR in the laboratory. Fifteen babies have died from the condition, with five linked to Zika. An additional 56 deaths are under investigation. Even one-third babies with a birth defect linked to the Zika virus also display eye abnormalities that could affect their vision. The World Health Organization (WHO) has declared the microcephaly condition, linked to the mosquito-borne virus, a global public health emergency ${ }^{13}$.

The full spectrum of outcomes that might be associated with infection during pregnancy and the factors that might increase risk to the fetus are not yet fully understood. More studies are planned to learn more about the risks of Zika virus infection during pregnancy ${ }^{14}$. In the worst affected region of Brazil approximately 1 percent of newborns are suspected of microcephaly ${ }^{15}$. On 4 February 2016, Spain has confirmed that a pregnant woman has been diagnosed with the Zika virus in her 28 weeks of pregnancy- the first such case in Europe. Ultrasonography has been done on in next week of this women, showed different fetal abnormalities with microcephaly. The health ministry said the woman had recently returned from Colombia, where it is believed she was infected ${ }^{16}$. Recently the Health department of Australia has confirmed two cases of Zika virus in Australia from passengers travelling from the Caribbean back to Sydney ${ }^{17}$. In Indonesia, the Eijkman Institute for Molecular Biology said, one Zika virus positive case is found from 103 dengue negative specimen who has no travelling history in Zika affected countries ${ }^{18}$. 


\section{Zika virus and Bangladesh}

Although Zika virus is not found in Bangladesh and neighboring countries but many sporadic cases of microcephaly are found during deliveries which are maximum under-reported. Even many cases of fever with maculopapular rash in outdoor department at tertiary level hospital but we do the tests against dengue only. It may be caused by Zika virus. It is almost alarming for us because the vector Aedes mosquito are available in Bangladesh and it is also responsible for spreading dengue fever throughout the Indian sub-continent region, especially in Bangladesh ${ }^{19}$. So, though it is spreading throughout the Americas recently, it could reach Bangladesh anytime. Concerns have grown even stronger in Bangladesh after news media in Thailand and Taiwan this week reported cases of the virus infection among locals. Both places are popular destinations for Bangladeshi travelers, increasing the risk of the virus also spreading here ${ }^{20}$. However, very recently the director of IEDCR (Institute of Epidemiology, Disease Control and Research) told the daily star, risk of zika virus infection in Bangladesh is low because this virus spread through Aedes mosquito and the mosquito's peak reproduction time here is during the rainy season, not now ${ }^{20}$.

\section{Virology}

Along with other viruses in Flavivirus family, Zika virus is enveloped and icosahedral with a non segmented, single stranded, positive-sense RNA genome $^{1,1}$. The pathogenesis of the virus is hypothesized to start with an infection of dendritic cells near the site of inoculation, followed by a spread to lymph nodes and the bloodstream ${ }^{21}$. Flaviviruses generally replicate in the cytoplasm, but Zika virus antigens have been found in infected cell nuclei ${ }^{22}$. Recent preliminary findings from sequences in the public domain uncovered a possible change in nonstructural protein 1 codon usage that may increase the viral replication rate in humans ${ }^{23}$.

\section{Transmission}

Zika virus is transmitted by daytime-active mosquitoes and has been isolated from a number of species in the genus Aedes, such as A. aegypti, and arboreal mosquitoes such as A. africanus, A. apicoargenteus, A. furcifer, A. hensilli, A. luteocephalus, and A. vitattus. Studies show that the extrinsic incubation period in mosquitoes is about 10 days $^{2}$. The vertebrate hosts of the virus are primarily monkeys and humans. Various reports have proved that Zika virus can transmitted by sexually, blood transfusion and even through breast milk $^{24}$. In 2015, Zika virus RNA was detected in the amniotic fluid of two fetuses, indicating that it had crossed the placenta and could cause a motherto-child infection ${ }^{25}$. On 20 January 2016, scientists from the state of Paraná, Brazil, detected genetic material of Zika virus in the placenta of a woman who had undergone an abortion due to the fetus's microcephaly, which confirmed that the virus is able to pass the placenta ${ }^{26}$. Very recently one case in Dallas, Texas has been confirmed that Zika virus can be transmitted by sexual contact and The CDC advises men with a pregnant partner to use condoms if they have traveled to an area with active Zika virus transmission. During February6-22, 2016, two confirmed and four probable cases of Zika virus sexual transmission were reported to CDC by health officials from multiple states. Median patient age was 22.5 years (range $=19-55$ years), and several women were pregnant. All cases occurred when the male partner was symptomatic or shortly after symptoms resolved, but further query will be needed that how long Zika virus persist in semen ${ }^{27,28}$. A Brazilian public health institute said active Zika virus has been detected in saliva and urine. The finding poses new questions for researchers trying to understand how the virus could spread ${ }^{29}$.

\section{Reservoir}

Zika virus is a mosquito-borne Flavivirus closely related to dengue virus. While mosquitoes are the vector, the reservoir species remains unknown, though serological evidence has been found in West African monkeys and rodents ${ }^{2,30}$.

\section{Clinical Feature and Sequelae}

The incubation period ranges between approximately three to 12 days after the bite of an infected mosquito. Most of the infections remain asymptomatic (between 60 to $80 \%$ ). Disease symptoms are usually mild and the disease in usually characterized by a short-lasting self-limiting febrile illness of 4-7 days duration without severe 
complications, with no associated fatalities and a low hospitalization rate. The main symptoms are macular-papular rash, fever, arthralgia, nonpurulent conjunctivitis/conjunctival hyperaemia, myalgia and headache. The rash often starts on the face and then spreads throughout the body. Less frequently, retro-orbital pain and gastro-intestinal signs are present ${ }^{2}$.

In a French Polynesian epidemic, 73 cases of Guillain- Barré syndrome (GBS) and other neurologic conditions occurred in a population of 270,000, which may be complications of Zika virus $^{31}$. In December 2015, the European Centre for Disease Prevention and Control issued a comprehensive update on the possible association of Zika virus with congenital microcephaly and GBS $^{31,32}$. However, further evidence is needed to establish a causal link between these neurological/neuro developmental impairments and infections with Zika virus ${ }^{31}$.

\section{Diagnosis}

It is difficult to diagnose Zika virus infection based on clinical signs and symptoms alone due to overlaps with other arboviruses that are endemic to similar areas ${ }^{31}$. Zika virus can be identified by RT-PCR in acutely ill patients. However, the period of viremia can be short and the World Health Organization recommends RT-PCR testing be done on serum collected within 1 to 3 days of symptom onset or on saliva or urine samples collected during the first 3 to 5 days ${ }^{30}$. Later on, serology through detection of specific $\operatorname{IgM}$ and IgG antibodies can be used. IgM can be detectable within 3 days of the onset of illness ${ }^{2}$. Serological cross-reactions can occur with closely related flaviviruses such as dengue virus ${ }^{2,33}$. Commercial assays for Zika diagnosis are not yet available ${ }^{31}$. The US Centers for Disease Control and Prevention advises that the differential diagnosis of suspected Zika virus infection is broad and includes, in addition to dengue and other viruses of this family ${ }^{30}$.

\section{Treatment}

There is currently no specific treatment for Zika virus infection. Care is supportive with treatment of pain, fever and other symptom ${ }^{31}$. Some authorities
*J Fardows, N Farhana, A B Siddique

have recommended against using aspirin and other NSAIDs as these have been associated with hemorrhagic syndrome when used for other flaviviruses ${ }^{32}$.

Zika virus had been relatively little studied until the major outbreak in 2015, and no specific antiviral treatments are available as yet. Advice to pregnant women is to avoid any risk of infection so far as possible, as once infected there is little that can be done beyond supportive treatment. One in vitro study found that Zika virus may be sensitive to interferon treatment, which is commonly used against other viral infections; however these results have not been tested in animals or humans ${ }^{34}$.

How to Treat Pregnant Women with Diagnoses of Zika Virus Disease

No specific antiviral treatment is available for Zika virus disease. Treatment is generally supportive and can include rest, fluids, and use of analgesics and antipyretics ${ }^{35}$. Fever should be treated with acetaminophen ${ }^{30}$. Although aspirin and other nonsteroidal anti-inflammatory drugs are not typically used in pregnancy, these medications should specifically be avoided until dengue can be ruled out to reduce the risk for hemorrhage ${ }^{35}$. In a pregnant woman with laboratory evidence of Zika virus in serum or amniotic fluid, serial ultrasounds should be considered to monitor fetal anatomy and growth every 3-4 weeks. Referral to a maternal-fetal medicine or infectious disease specialist with expertise in pregnancy management is recommended ${ }^{36}$.

\section{Prevention and Control}

There is currently no vaccine, but development is a priority of the National Institutes of Health ${ }^{31,32}$. The virus is spread by mosquitoes, making vector control and avoidance an essential element to disease control. The US Centers for Disease Control recommends some preventive measures: exposed skin should be covered by long-sleeved shirts and long pants, insect repellent should be used, permethrin-treated clothing and gear should be used (such as boots, pants, socks, and tents) and airconditioned rooms should be required for stay and sleep ${ }^{31}$. 
permethrin-treated clothing and gear should be used (such as boots, pants, socks, and tents) and airconditioned rooms should be required for stay and sleep $^{31}$.

\section{Zika and Microcephaly}

Data suggests that newborn babies of mothers who had a Zika virus infection during the first trimester of pregnancy are at an increased risk of microcephaly ${ }^{37}$. In December 2015 it was suspected that a trans-placental infection of the fetus may lead to microcephaly and brain damage ${ }^{38,39}$. The Brazilian Ministry of Health has confirmed the relation between the Zika virus and microcephaly ${ }^{39}$. Pan Americal Health Organization (PAHO) reported the identification of Zika virus RNA by reverse transcription-polymerase chain reaction (RT-PCR) in amniotic fluid samples from two pregnant women whose fetuses were found to have microcephaly by prenatal ultrasound, and the identification of Zika virus RNA from multiple body tissues, including the brain, of an infant with microcephaly who died in the immediate neonatal period ${ }^{40}$. Very recently one of the most senior public health officials has also revealed the strongest evidence of mother to fetus transmission of Zika virus. A cohort study was done for evaluation of association between Zika virus and microcephaly, total 37 infants with microcephaly were found, only 35 cases are included in this report. Two infants with microcephaly were excluded from the original cohort of 37 babies: one had autosomal recessive microcephaly and one had cytomegalovirus infection. Overall, 26 (74\%) mothers of infants with microcephaly reported a rash during the first $(\mathrm{n}=21)$ or second (5) trimester or residence in or travel during pregnancy to areas where Zika virus is circulating was confirmed for all mothers, including women without a history of $\operatorname{rash}^{40,41}$.

\section{January 2016 CDC travel alert}

Because of the "growing evidence of a link between Zika and microcephaly" the Centers for Disease Control and Prevention (CDC) issued a travel alert on 15 January 2016 advising pregnant women to consider postponing travel to the following countries and territories: Brazil, Colombia, El Salvador, French Guiana, Guatemala, Haiti, Honduras, Martinique, Mexico, Panama, Paraguay, Suriname,
Venezuela, and the Commonwealth of Puerto Rico ${ }^{9}$. The agency also suggested that women thinking about becoming pregnant should consult with their physicians before traveling 9,42 .

Recommendations for Pregnant Women with History of Travel to an Area of Zika Virus Transmission

Health care providers should ask all pregnant women about recent travel. Women who traveled to an area with ongoing Zika virus transmission during pregnancy should be evaluated for Zika virus infection and tested in accordance with CDC Guidance ${ }^{37}$.

Zika virus testing of maternal serum includes reverse transcription-polymerase chain reaction (RT-PCR) testing for symptomatic patients with onset of symptoms within the previous week. Immunoglobulin $\mathrm{M}$ (IgM) testing should be performed on specimens collected ?4 days after onset of symptoms ${ }^{37}$. Zika virus RT-PCR testing can be performed on amniotic fluid ${ }^{43}$. Currently, it is unknown how sensitive or specific this test is for congenital infection. Also, it is unknown if a positive result is predictive of a subsequent fetal abnormality. However, amniocentesis is associated with an overall $0.1 \%$ risk of pregnancy loss when performed at less than 24 weeks of gestation ${ }^{44}$. For a live birth with evidence of maternal or fetal Zika virus infection, the following tests are recommended: histopathologic examination of the placenta and umbilical cord; testing of frozen placental tissue and cord tissue for Zika virus RNA; and testing of cord blood for $\mathrm{Zika}^{45}$.

\section{January 2016 WHO recommendation}

On 17 January 2016 the Pan American Health Organization (PAHO), the regional office of the United Nations' World Health Organization, considering the increased number of cases of congenital anomalies, Guillain-Barré syndrome and other neurological or autoimmune syndromes in Zika-affected areas, recommended that its member states "establish and maintain the capacity to detect and confirm Zika virus cases, prepare healthcare facilities to respond to a possible increase demand of specialized care for neurological syndromes, as well to strengthen antenatal care" 46 . 


\section{Conclusion}

The main goal currently being addressed with Zika virus is finding ways of treatment and effective vaccines that can be applied to humans especially pregnant women. Although Zika virus infection is not a problem right now for most populations outside America, it has the potential to be alarming from the point of view in global health in the future.

\section{References}

1. Faye $\mathrm{O}$, Freire $\mathrm{CC}$, Iamarino A, Faye $\mathrm{O}$, de Oliveira JV, Diallo M. Molecular Evolution of Zika Virus during Its Emergence in the 20(th) Century. PLoS Negl Trop Dis 2014; 8(1):e2636.

2. Hayes EB. Zika virus outside Africa. Emerg Infect Dis 2009; 15(9):1347-50.

3. Cristiane WC, Igor ADP, Mariana K, Moreno SR, Monaise MOS, Gubio SC. Outbreak of Exanthematous Illness Associated with Zika, Chikungunya, and Dengue Viruses, Salvador, Brazil. Emerg Infec Dis J 2015; 21(12):2274.

4. Musso D, Nilles EJ, Cao-Lormeau VM. Rapid spread of emerging Zika virus in the Pacific area. Clin Microbiol Infect 2014; 20(10):595-6.

5. Diallo D, Sall AA, Diagne CT, Faye O, Faye O, $\mathrm{Ba}$ Y. Zika virus emergence in mosquitoes in southeastern Senegal, 2011. PLoS One 2014; 9(10):e109442.

6. Altman LK. "Little-Known Virus Challenges a FarFlung Health System". New York Times, 2007.

7. Duffy MR, Chen TH, Hancock WT, Powers AM, Kool JL, Lanciotti RS. Zika virus outbreak on Yap Island, Federated States of Micronesia. N Engl J Med 2009; 360(24):2536-43.

8. Center for Diseases Control and Prevention. "Zika Travel Health Notices" [internat]. CDC; 2016 [cited on 4 Jan, 2016] (Available at: www.cdc.gov). CDC.

9. Lowes R. "CDC Issues Zika Travel Alert",2016. (Available at: www.cdc.gov.CDC).

10. "Zika virus: Advice for those planning to travel to outbreak areas". ITV News, 2016. (Available at: www.itv.com/news/2016.../).

11. "Pregnant Irish women warned over Zika virus in central and South America". ITV news, 2016. (Available at: www.itv.com/news/2016.../).

12. "Zika: Olympics plans announced by Rio authorities". BBC news, 2016. (Available at:www.bbc/news/ 564322../).

13. LaMotte $\mathrm{S}$, Peason M. "CDC issues new safe sex guideline-around Zika virus".CNN, 2016. (Availableat: www.cnn.com/2016/02/05/ health/ zika-urine-saliva/).

14. European Centre for Disease Prevention and Control "Microcephaly in Brazil potentially linked to the Zika virus epidemic [internat]. ECDC; 2016 [cited on 10 Feb, 2016]. (Available at: www.ecdc.gov.ECDC).

15. "Brazil Zika outbreak: More babies born with birth defects". BBC news, 2016. (Available at:www.bbc.com/).

16. "Zika virus pregnancy case confirmed in Spainfirst in Europe". BBC news, 2016. (Available at:www.bbc.co.uk/ news/ world-europe35490524).

17. "Two confirmed cases of Zika virus in Australia, researchers warn after WHO emergency declaration". BBC news, 2016. (Available at:www.bbc.com/).

18. "Zika virus found in Indonesia:Researchers". BBC news, 2016. (Available at: www.bbc.com).

19. Hasib NI. "Zika a cause of concern for Bangladesh"? BD news, 2016. Available at:bd news 24.com. (Available at: bdnews24.com/.../2016/.../bangladesh-gears-upzika-viru..).

20. Azad A, Mohmood A. Now Zika declared global emergency by WHO. Dhaka tribune news, 2016. (Available at: issuu.com/ dhakatribune/ .../160125200807-359e166098b 4431781fad53).

21. Hamel R, Dejarnac O, Wichit S, Ekchariyawat P, Neyret A, Luplertlop N, Perera-Lecoin M, Surasombatpattana P, Talignani L, Thomas F, Cao-Lormeau VM, Choumet V, Briant L, Desprès P, Amara A, Yssel H, Missé D. "Biology of Zika Virus Infection in Human Skin Cells". J Virol 2015; 89 (17): 8880-96.

22. Buckley, A.; Gould, E. A. "Detection of virus specific antigen in the nuclei or nucleoli of cells infected with Zika or Langat virus". J Gen Virol 1988; 69 (8): 1913-20.

23. Oehler E, Watrin L, Larre P. Zika virus infection complicated by Guillain-Barre syndromecase report, French Polynesia, 2013. Euro Surveill 2014;19:4-6.

24. Faye OF, Caio CM, Iamarino A, Faye O, Oliveira JVC, Diallo M. "Molecular Evolution of Zika Virus during Its Emergence in the 20th 
Century". PLoS Neglec Tropic Dis 2006; 8 (1): e2636.

25. Vogel G. "Fast-spreading virus may cause severe birth defects". Science News, 2015.(Available at:www.sciencenews.com/).

26. Enserink M. "Sex After a Field Trip Yields Scientific First". Science News, 2011. (Available at:www. sciencenews.com/).

27. Hills SL, Russel K, Hennessey M, Oster MD. "Transmission of Zika virus through sexual contact with travelers to areas of ongoing transmission- continental United States, 2016". Morb Mortal Wkly Rep 2016; 65 (8): 215-16.

28. "Zika Outbreak Updates: Puerto Rico Declares State of Emergency". ABC news, 2016. (Available at: abcnews.go.com > Topics > Lifestyle , Health).

29. "Zika virus transmission by sexually". CNN, 2016. (Available at:www.cnn.com/).

30. Gatherer D, Kohl A. "Zika virus: a previously slow pandemic spreads rapidly through the Americas". J Gen Virol 2015; 4: 56-60.

31. Fauci, Anthony S.; Morens, David M. "Zika Virus in the Americas - Yet Another Arbovirus Threat". New England J Med 2016; 3:345-51.

32. European Centre for Disease Prevention and Control "Rapid risk assessment: Zika virus epidemic in the Americas: potential association with microcephaly and Guillain-Barré syndrome" [internate]. ECDC; 2015 [cited on 4 Feb, 2016]. (Available at:www.ecdc.gov. ECDC).

33. Lanciotti RS, Kosoy OL, Laven JJ, et al. "Genetic and serologic properties of Zika virus associated with an epidemic, Yap State, Micronesia, 2007". Emerg Infec Dis 2007; 14: 1232-9.

34. Petersen EE, Staples JE, Meaney-Delman D, Fischer M, Ellington SR, Callaghan WM, Jamieson DJ. "Interim Guidelines for Pregnant Women During a Zika Virus Outbreak - United States, 2016". Morb Mortal Wkly Rep 2016; 65(2): 30-3.

35. Center for Diseases Control and Prevention. CDC health advisory: recognizing, managing, and reporting Zika virus infections in travelers returning from Central America, South America, the Caribbean and Mexico [internat]. CDC; 2016 [cited on 17 Jan, 2016]. (Available at: www.cdc.gov.CDC).
36. Rasmussen SA, Kissin DM, Yeung LF. PandemicInfluenza and Pregnancy Working Group. Preparing for influenza after 2009 H1N1: special considerations for pregnant women and newborns. Am J Obstet Gynecol 2011; 204(1): 13-20.

37. Zika virus. For health care providers: diagnostic testing, Atlanta, GA: US Department of Health and Human Services, Centers for Diseases Control and Prevention, 2015. (Available at: http://www.cdc.gov/ zika/hc providers/diagnostic.html).

38. Beaubien J. "The Zika Virus Takes A Frightening Turn - And Raises Many Questions". CNN, 2016. (Available at:www.cnn.com/).

39. Darlington S. "Brazil warns against pregnancy due to spreading virus". CNN, 2015. (Available at:www.cnn.com/).

40. Center for Diseases Control and Prevention .Notice from:Brain and placental tissue from two congenitally infected newborn and two fetal losses- Brazil, 2015.MMWR 2015; 65 (6): 1-2.

41. Schuler-Faccini L, Ribiro EM, Feitosa MD, Ian ML. Possible Association Between Zika Virus Infection and Microcephaly - Brazil, 2015. Morb Mortal Wkly Rep 2016; 65(3):59-62.

42. "Zika virus: strongest evidence yet of effect on babies". BBC news, 2016.(Available at: www.bbc.com/news/world-latin-america/ 35543371).

43. CDC issues interim travel guidance related to Zika virus for 14 Countries and Territories in Central and South America and the Caribbean, 2016 [internat]. (Available at: http: // www.cdc.gov/media/ releases/2016/ s0315-zikavirus-travel.html).

44. Besnard M, Lastere S, Teissier A, Cao-Lormeau $\mathrm{V}$, Musso D. Evidence of perinatal transmission of Zika virus, French Polynesia, 2013 and 2014. Euro Surveill 2014; 19: 13-6.

45. Akolekar R, Beta J, Picciarelli G, Ogilvie C, D' Antonio F. Procedure-related risk of miscarriage following amniocentesis and chorionic villus sampling: a systematic review and meta-analysis. Ultrasound Obstet Gynecol 2015; 45: 16-26.

46. Neurological syndrome, congenital malformations, and Zika virus infection Epidemiological Update, 2016. Available at: http://www.paho. org/hq/index. php?option $=$ com $_{-}$content $\&$ view $=$ category \&layout $=$ blog\&id $=1218 \&$ Itemid $=2291$ 